\title{
GLENN A. BLACK, 1900-1964
}

\author{
James H. Kellar
}

$G$ LENN A. BLACK, archaeological field director for the Indiana Historical Society, died unexpectedly from a heart attack in Evansville, Indiana, on September 2, 1964.

Born in Indianapolis August 15, 1900, Black attended public schools in that city and graduated from Arsenal Technical High School. He entered the field of archaeology before there were abundant opportunities for formal training - he commented that he taught at the only university he ever attended - and was, like many colleagues of his generation, essentially self-taught and drawn to prehistory by early collecting activities, a sense of problem, and an awareness of the past that was slipping beyond recall. The level of his achievements was recognized by the award of an Sc.D. from Wabash College in 1951.

Black's field experience was largely confined to Indiana, but his career spanned the years during which prehistoric research attained some degree of maturity, and he had an important role in this development. His ever-present concern with raising professional standards was reflected in his having been a founder of the Society for American Archaeology and having held nearly every office in the organization (Vice-President, 1939-40; Council Member, 1940-41; President, 1941-42; Treasurer, 194751). His systematic dissection of the Nowlin Mound in southeastern Indiana and the subsequent report remain as significant landmarks in the history of American field archaeology. When archaeologists were beginning to perceive the richness of prehistory in the eastern United States and to define the problems that motivate research to this day, he was an active participant at every major conference. A sustained interest in new approaches to field methodology is evidenced by his having been the first prehistorian to test systematically the potential of the proton magnetometer on a New World site; this was supported by two National Science Foundation grants.

Less well-known, at least to the more recent generation of archaeologists, but of importance to developing interests in the 1930's and 1940's, was his association with a small Indiana-centered group concerned with the anthropological evaluation of the Walam Olum, the purported migration legend of the Delaware Indians. Sustained by the active interest and participation of Eli Lilly, support was provided for the University of Michigan's Ceramic Repository, a dendrochronological lab at the University of Chicago, and numerous field projects in several eastern states. Additionally, fellowship grants ultimately resulted in the establishment of an anthropology department at Indiana University.

Black's affiliation with the Indiana Historical Society began in the early 1930's. After a training period at the Ohio State Museum with H. C. Shetrone and contact with Warren K. Moorehead, he inaugurated a program of archaeological survey and excavation that took him into almost every sector of Indiana. His early publications reflect a lifelong interest in field techniques and respect for small detail. Probably no more precise description of mound structure is in print than that contained in the Nowlin Mound report. Black was intrigued by the possibility of prehistoric-historic continuities, and surveys were undertaken in Allen and St. Joseph counties, the scene of early trading posts, but his efforts were abortive. This experience led him to believe that future investigations in this direction were fruitless in Indiana. Since he was the only archaeologist in Indiana for most of his professional life, he directed the accumulation of a tremendous reservoir of data, all of which he systematically maintained. In 1938, the Indiana Historical Society purchased the Angel site, a large Middle Mississippi village near Evansville. Though the primary objective was to preserve this important resource from urban encroachment, Black viewed this acquisition as offering a unique opportunity for longterm study of a single archaeological context, and he devoted 27 years to the study of this site. Excavations were undertaken during almost every one of these years: first, with a large WPA crew and later with the assistance of students enrolled in a summer field course. Work was continuing in a large truncate mound at his death. Needless to say, millions of material items, hundreds of houses, and massive amounts of other evidence for human occupation were recovered, and Glenn became as much a part of the site as the villagers who occupied it some five centuries earlier. He had all but completed 
a massive and definitive two-volume report, the publication of which will make a significant contribution to New World prehistory.

Almost three decades of work at Angel Mounds markedly conditioned Black's views on the nature of archaeology. He was very much aware of criticisms directed at him for devoting so many resources to a single site, but the rich variability encountered in various areas at Angel made him highly skeptical of "testing" operations, and he wanted no part in such programs. In his view, the major aim of the prehistorian was to produce a site "ethnography," and this could not be accomplished with data derived from a few one-meter pits. When one of my colleagues and I proposed to undertake excavations at a site culturally and areally more complex than Angel, Black made us painfully aware of his views. However, once work was begun, Glenn was eager to volunteer his almost inexhaustible knowledge of the area involved and made available aerial photographs, notes, and substantial surface collections.

For 16 years Black made weekly trips of 250 miles from Evansville to Indiana University where he taught courses in North American prehistory. The summer months were spent directing the University's field school, and 120 students from all portions of the Americas received a solid introduction to "dirt" archaeology. His lectures were factual and superbly organized; contacts with students were highly personal and not restricted to those sharing an interest in prehistory. As the university milieu became more detached with ever-increasing size, Black was easily approached by the rawest undergraduate and more than once saw students through some financial crisis. He viewed with disdain the inevitable red tape of a large institution and was often more willing to use his own resources than to wrestle with a supposed bureaucratic structure. His associations with students kept him coming back to Bloomington long after he realized that the weekly jaunt interfered with his already-overscheduled existence. It is of interest to note that he maintained a complete and up-to-date file on all former students.

Glenn seemed to have few interests other than those related to archaeology, but the same serious intensity that marked his professional involvement was transferred to these. During the 1920's, he organized and played percussion in a small dance combo and this love for "Dixie-

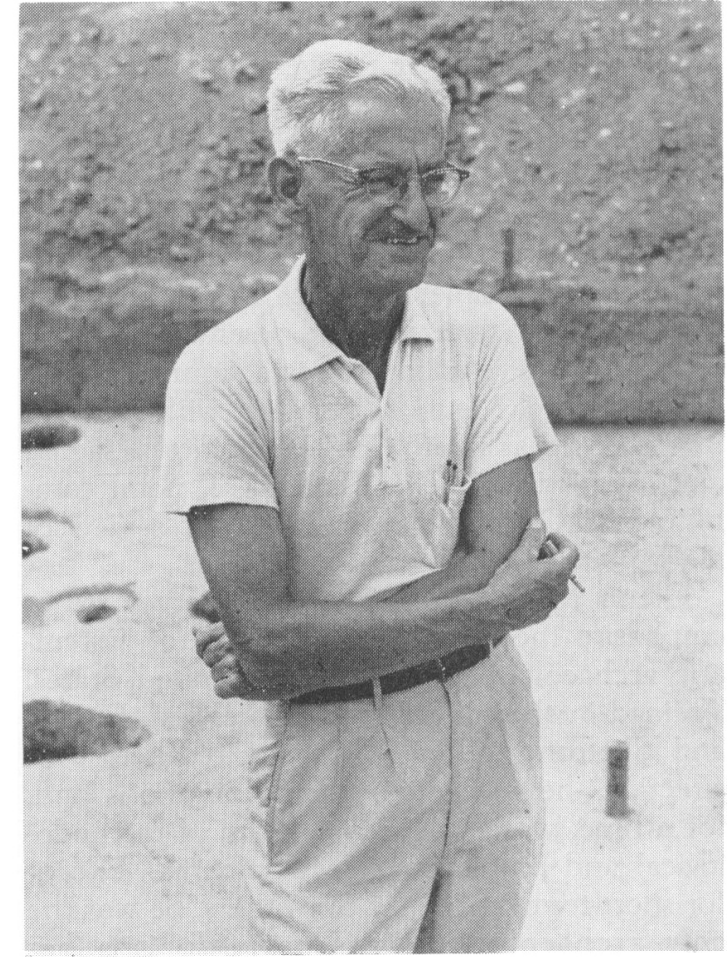

Glenn A. Black

land" jazz persisted. Golf had been an earlier recreation (he shot in the low 80 's), but the drive to improve interfered with archaeology and the sport was dropped. Technology was an abiding interest and his office and laboratory were well supplied with gadgets, all of which he used. His collection of photographic gear went far beyond that needed for archaeology. Lapidary work occupied his attention in recent years. However, not content with a casual hobby, he utilized his considerable knowledge of geology, read widely in all aspects of the craft, established contacts in the United States and abroad, and assembled an outstanding collection of minerals and slab material. A small basement workshop evolved into a fully equipped lapidary center, and his interest spread into enameling and metal casting. It was said that he faceted every stone susceptible to such treatment. Highly complex stone-cutting problems were undertaken, and some of his results have considerable value.

Archaeological field work was approached in the same way. A site represented a problem to be solved, and only through technical excellence could solutions be found. $\mathrm{He}$ argued at 
one time that any skilled person could write the report if the data were recovered with precision and given full documentation. Black therefore became an accomplished surveyor, cartographer, draftsman, and photographer; he surrounded himself with all possible technical aids; field notes were meticulously kept; and all records having any possible relevance to the problems at hand were systematically assembled. I suspect that most students, after a summer in the field at Angel Mounds, were left with the firm impression that an archaeological site was sacred and excavation involved a kind of moral commitment. Certainly, this was Glenn's view of his work.

Glenn Black's untimely death serves to reemphasize the comparative recency of systematic archaeology in the eastern United States. Trained in the tradition of Moorehead, Fowke, and Shetrone, all of whom he recalled with affection, he recognized their limitations and, for a time, was in the mainstream of methodological and professional developments. Except for short-term work by a few others, he was the only archaeologist the state of Indiana has known, and his knowledge of the area was prodigious. In this capacity he oversaw the assembling of a truly monumental archaeological collection. One wishes that more of his knowledge had been written down, but he was unwilling to describe fragments and he assumed that everyone else was equally well informed. Of course no one was, but whatever may be accomplished in Indiana in the years ahead will be dependent in some measure on what Black was responsible for conserving. Certainly, the 27 years of devotion, and devotion it was, to a single site is unique in American archaeology, and the analytical potential of the derived data is limited only by the imagination and ingenuity of those who follow.

\section{Publications of Glenn A. Black}

1933 The Archaeology of Greene County. Indiana His. tory Bulletin, Vol. 10, No. 5. Indianapolis.

1934 Archaeological Survey of Dearborn and Ohio Counties, Indiana. Indiana History Bulletin, Vol. 11, No. 7. Indianapolis.

Preliterate Cultures in Indiana. Indiana History Bulletin, Vol. 11, No. 5, pp. 114-24. Indianapolis.

1936 (with Paul Weer) Outlines Suggesting Classification Problems. Indiana Academy of Science Proceedings, Vol. 45, pp. 37-47. Indianapolis.

(with Paul Weer) A Proposed Terminology for Shape Classification of Artifacts. American Antiquity, Vol. 1, No. 4, pp. 280-94. Menasha.
1937 Excavation of the Nowlin Mound. Indiana History Bulletin, Vol. 14, No. 2. Indianapolis.

1940 Archaeology at the Angel Mounds Site. Indiana Academy of Science Proceedings, Vol. 50, pp. 25-6. Indianapolis.

Cultural Complexities of Southwestern Indiana. Indiana Academy of Science Proceedings, Vol. 50, pp. 33-5. Indianapolis.

Report on Progress at Angel Mounds. Indiana Academy of Science Proceedings, Vol. 49, p. 22. Indianapolis.

1941 Trait Complexes at the Angel Site. Indiana Academy of Science Proceedings, Vol. 51, pp. 34-43. Indianapolis.

1944 Angel Site, Vanderburgh County, Indiana: An Introduction. Indiana Historical Society, Prehistory Research Series, Vol. 2, No. 5. Indianapolis.

1945 The Cato Site - Pike County, Indiana. Indiana Academy of Science Proceedings, Vol. 55, pp. 1822. Indianapolis.

Review: Contributions to the Archaeology of the Illinois Valley, by Frank C. Baker and others. American Antiquity, Vol. 10, No. 3, pp. 315-18. Menasha.

1946 Some Rare or New Middle Mississippi Traits. Indiana Academy of Science Proceedings, Vol. 56, p. 20. Indianapolis.

1947 A Critique of Some Archaeological Field Methods [abstract]. Indiana Academy of Science Proceedings, Vol. 57, p. 16. Indianapolis.

1948 An Indiana Archaeological Field School. Indiana Academy of Science Proceedings, Vol. 58, p. 47. Indianapolis.

Early Hoosier Archaeologists. Indiana Academy of Science Proceedings, Vol. 58, p. 251. Indianapolis.

1949 "Tepexpan Man," a Critique of Method. American Antiquity, Vol. 14, No. 4, pp. 344-6. Menasha.

1952 Archaeological Field Method and C14 Dating [abstract]. Indiana Academy of Science Proceedings, Vol. 61, p. 16. Indianapolis.

A Primer of Hoosier Prehistory. Prepared for Indiana History Workshop, April 6-9. Mimeographed.

1953 Review: "Archaeology of the Illinois Valley: 1950," by Donald E. Wray, in Archaeology of Eastern United States. American Antiquity, Vol. 19, No. 2, p. 179. Salt Lake City.

Review: "Archaeology of the Lower Ohio Valley," by Moreau S. Maxwell in Archaeology of Eastern United States, edited by James B. Griffin. American Antiquity, Vol. 19, No. 2, p. 180. Salt Lake City.

Review: "Culture Sequences in the Lower Missouri Valley," by Carl H. Chapman, in Archaeology of Eastern United States, edited by James B. Griffin. American Antiquity, Vol. 19, No. 2, p. 179. Salt Lake City.

Review: "Hopewellian Dress in Illinois," by Thorne Deuel in Archaeology of Eastern United States, edited by James B. Griffin. American Antiquity, Vol. 19, No. 2, pp. 179-80. Salt Lake City. 
1954 An Archaeological Consideration of the Walam Olum. Walam Olum or Red Score, The Migration Legend of the Lenni Lenape or Delaware Indians, pp. 292-348. Chicago and Crawfordsville, Indiana.

The Historic Indian of the Ohio Valley: An Archaeologist's View. Ohio State Archaeological and Historical Quarterly, Vol. 63, No. 2, pp. 155-65. Columbus (also in Ethnohistory, No. 2).

1955 A Statistical Justification for 15 Years Excavation at One Archaeological Site [abstract]. Indiana Academy of Science Proceedings, Vol. 64, p. 51. Indianapolis.

1956 Indiana's Prehistoric Cultures. Readings in Indiana History, pp. 1-5. Indiana Historical Bureau, Indianapolis.

1957 Aboriginal Man and Nature. Prepared for the Indiana History Workshop, April 25-28. Mimeographed.
1958 " $A$ " is for Axe. Indiana Historical Society, Indianapolis.

1961 Review: Illinois Archaeology, edited by E. A. Bluhm. American Antiquity, Vol. 26, No. 1, p. 133. Salt Lake City.

"... that what is past may not be forever lost . . ." Indiana History Bulletin, Vol. 38, No. 4, pp. 5i-69. Indianapolis.

1962 (with Richard B. Johnston) Two Graves in Warrick County, Indiana, near Angel Site. Indiana Historical Society, Prehistory Research Series, Vol. 4, No. 1. Indianapolis.

1963 (with Richard B. Johnston) A Test of Magnetometry as an Aid to Archaeology. American Antiquity, Vol. 28, No. 1, pp. 199-205. Salt Lake City.

INDIANA UNIVERSITY Bloomington, Indiana May, 1965 